Nidhomul Haq: Jurnal Manajemen Pendidikan Islam

Accredited Ristekdikti: 28/E/KPT/2019

DOI: https://doi.org/10.31538/ndh.v6i3.1776

Journal Homepage: http://e-journal.ikhac.ac.id/index.php/nidhomulhaq
E-ISSN: 2503-1481

pp: 526-536

\title{
Prospects of Digital Literature and Its Implications on Increasing Learning Outcomes During The Covid-19 Pandemic
}

\author{
Samsul Susilawati \\ Pascasarjana Universitas Islam Negeri Maulana Malik Ibrahim, Malang, Indonesia \\ susilawati@pips.uin-malang.ac.id
}

Received: 12-08-2021

Revised: 26-10-2021

Accepted: 10-11-2021

\section{Abstract}

Keywords:

Digital Literacy, Learning Outcomes, Covid-19 pandemic
The implementation of the Education Policy in the Covid-19 Emergency Period requires educators to carry out a learning innovation, namely selfdirected learning based on digital literacy. This progress has presented both challenges and opportunities for human life. Humans can enjoy the convenience of accessing information and can enjoy the facilities of digital technology freely. Digital literacy needs to be developed in the world of education today to improve student learning outcomes. The purpose of this research is to determine the effect of the application of digital literacy on improving the learning outcomes of students of the Social Science Education Department, Faculty of Tarbiyah and Teacher Training, in the Development of Learning Resources and Media Courses at UIN Maulana Malik Ibrahim Malang. This research uses quantitative methods with a simple linear regression approach. The research data were collected through questionnaires and documentation. The questionnaire was distributed to 77 samples from 152 populations with the sampling technique using purposive sampling. Based on the results of the study, it was obtained $\mathrm{R}$ of 0.667 , which indicates that the relationship between the application of digital literacy (variable $\mathrm{X}$ ) and learning outcomes (Variable $\mathrm{Y}$ ) is strong. The results of the $\mathrm{F}$ test prove that $\mathrm{F} 68,688>\mathrm{F} 4.39$, then the alternative hypothesis $(H)$ is accepted and the null hypothesis $(H)$ is rejected. The results and conclusions of this study indicate that the application of digital literacy has an influence on improving student learning outcomes.

\footnotetext{
Kata kunci.

Literasi Digital, Hasil

Belajar, Pandemi Covid-19
}

\begin{abstract}
Abstrak
Pelaksanaan Kebijakan Pendidikan dalam Masa Darurat Covid-19, menuntut pendidik untuk melakukan sebuab inovasi pembelajaran, yaitu pembelejaran self directed learning berbasis literasi digital. Kemajuan tersebut telah menghadirkan tantangan sekaligus peluang bagi kehidupan manusia. Manusia bisa menikmati kemudahan dalam mengakses suatu informasi dan dapat menikmati fasilitas dari teknologi digital dengan bebas. Literasi digital perlu dikembangkan dalam dunia pendidikan saat ini untuk meningkatkan hasil belajar Mabasiswa.Tujuan dari penelitian ini ialah untuk mengetahui pengaruh penerapan literasi digital terhadap meningkatkan hasil belajar Mahasiswa Jurusan Pendidikan IPS Fakultas Ilmu Tarbiyah dan Keguruan, Pada Mata Kuliah Pengembangan Sumber dan Media Pembelajaran UIN Maulana Malik Ibrabim Malang. Penelitian ini menggunakan metode kuantitatif dengan pendekatan regresi linier sederhana. Data penelitian ini
\end{abstract}


dikumpulkan melalui angket dan dokumentasi. Angket diedarkan kepada 77 sampel dari 152 populasi dengan teknik pengambilan sampel menggunakan Purposive Sampling. Berdasarkan hasil penelitian diperoleh R sebesar 0,667, yang menunjukkan bahwa bubungan antara penerapan literasi digital (variabel X) dan Hasil Belajar (Variabel Y) tergolong kuat. Hasil uji F terbukti babwa F 68.688 > F 4.39, maka bipotesis alternative $(H)$ diterima dan bipotesis nol $(H)$ ditolak. Hasil dan kesimpulan penelitian ini menunjukkan bahwa penerapan literasi digital memiliki pengarub terbadap peningkatan Hasil Belajar Mahasiswa.

\section{INTRODUCTION}

Literacy has become a part of human life and development, from prehistoric times to modern times. The advancement of transportation and telecommunication infrastructure, including the emergence of the telegraph and the internet, is a major factor in globalization which has increasingly driven the interdependence of economic and cultural activities. Some argue that the beginnings of globalization occurred in the modern era (Asari, Kurniawan, Ansor, Bagus, \& Rahma, 2019). Over time, the standard of human life develops. From not knowing writing to giving birth to thoughts of making code codes with numbers and letters so that humans are said to be able to think or are now called literacy abilities.

Digital literacy is the interests, attitudes and abilities of individuals who directly use digital technology and communication tools to access, manage, integrate, analyze and evaluate information, build new knowledge, create and communicate with others in order to participate effectively in society. Prepare graduates who are qualified and able to compete globally, and mastering technological developments is important for everyone and important for the future of a country (Assidik, 2018). Thus, the support and role of education is expected to increase the nation's competitiveness in the midst of global competition with the rapid development of information technology. The great wave of the digital world today is unstoppable, which delivers anyone who can make good use of it but often can destroy one's dignity in various ways. Human lack of understanding of the digital world has made various misuses of digital media occur at the personal, social and national levels. Therefore, improving the quality of learning is one of the challenges for education actors in Indonesia (Giovanni \& Komariah, 2020). The development of the world is now entering the era of society 5.0 where information technology has become the basis of human life. Preparing graduates who are qualified and able to compete globally, and master technological developments are important for everyone and important for the future of a country (Pratiwi \& Pritanova, 2017) (Fajeriah, Tadulako, \& Indonesia, 2021). Digital literacy is the ability to understand and use information in various forms from a very wide variety of sources accessed through computer devices. Learning achievement is the result of learning activities, namely the extent to which students master the subject matter being taught, followed by the emergence of a feeling of satisfaction that they have done something well.

Digital media makes it easy for each user to share information. Sources of information can come from anywhere. The digital age is inevitable (Khokhar, 2016). Anyone can easily make good use of it, but not infrequently it can also destroy someone. The public's lack of understanding of digital media leads to abuse that affects personal and social life. Social media exists as part of the development of the internet (Uswatun Khasanah \& Herina, 2019). Its presence offers a new and easy way to interact, communicate and socialize with the support of interesting features. The number of social media users in Indonesia is dominated by teenagers so 
that the impact is very much felt by teenagers. Good use can improve performance, on the other hand, bad use can have a negative impact on children and adolescents (Fransori, Sulistijani, \& Youlinda Parwis, 2019). Digital literacy is an individual's ability to apply functional skills to digital devices so that a person can find and select information, think critically, be creative, collaborate with others, communicate effectively, and still ignore electronic security and the developing socio-cultural context [8]. In the context of education, good digital literacy also plays a role in developing one's knowledge of certain subject matter by encouraging students' curiosity and creativity (Tinggi, 2019). The implementation of education is held as a lifelong process of cultivating and empowering students. This principle is in accordance with the general provisions of the 2003 National Education System Law article 1 paragraph 1(Utami, 2019) It is stated that education is a conscious and planned effort to create an atmosphere of learning and the learning process so that students actively develop their potential to have the strength of religious spiritual character, self-control, personality, intelligence, noble character, and skills needed by themselves, society, the nation, and religion.

Based on preliminary observations and interviews conducted by researchers with Librarian Lecturers and students in the Social Studies Education Department, Learning Resources and Media Development Courses at the Faculty of Tarbiyah and Teacher Training, UIN Maulana Malik Ibrahim Malang, students are given the freedom to use digital devices to carry out the information search process to answer assignments. -school assignment. However, in the school environment students are not allowed to bring cellphones except for laptops. To support students in searching for information via digital, the Campus of the Faculty of Tarbiyah and Teacher Training at UIN Maulana Malik Ibrahim Malang provides computers and wifi in the library room. It can be concluded that the campus has facilitated the learning process by implementing digital literacy. Lecturers teach digital literacy to students and students have the knowledge and freedom to seek information from digital sources. However, students' technical abilities in using digital technology and understanding of valid and reliable information sources are one of the obstacles in doing assignments. Based on the descriptions and problems above, the researchers are interested in examining this, with the title "The effect of digital literacy on improving learning outcomes of students of the Social Studies Education Department, Faculty of Tarbiyah and Teacher Training, UIN Maulana Malik Ibrahim Malang".

\section{METHOD}

This type of research used in this research is quantitative research methods (Sugiyono, 2012). Quantitative research is a type of research that uses a deductive-inductive approach. Quantitative research is a study that uses the logic of the verification hypothesis which starts with deductive thinking to derive the hypothesis then carries out testing in the field and the conclusion or hypothesis is drawn based on empirical data. (Suliyanto, 2018). This study aims to test whether there is a relationship between digital literacy and student achievement. This study consists of two variables, namely the application of digital literacy $(\mathrm{X})$ as the independent variable and the improvement of learning outcomes $(\mathrm{Y})$ as the dependent variable. This quantitative research uses a simple linear regression approach. The general equation for simple linear regression is $\mathrm{Y}=\mathrm{a}+\mathrm{bX}$. The research location is in the Department of Social Sciences Education, Faculty of Tarbiyah and Teacher Training, State Islamic University of Malang. While 
the time span of the research that the author conducted was from the initial observation, namely from March 17, 2020 to July 8, 2020. The data collection techniques in this study were using a questionnaire technique.(Tinggi, 2019). Below is a description of the relationship between variables, indicators, instruments, and data forms (measurement scale):

Table. 1 Relationship of Variables, Indicators, Instruments, and Data Forms

\begin{tabular}{|c|c|c|c|c|}
\hline No & Variable & Indicator & Instrument & Data \\
\hline 1 & $\begin{array}{l}\text { Application of } \\
\text { Digital Literacy }\end{array}$ & $\begin{array}{l}\text { 1. Search the internet } \\
\text { 2. Guide the hypertext direction } \\
\text { 3. Evaluation of information content } \\
\text { 4.Compilation of knowledge }\end{array}$ & Questionnaire & Ordinal \\
\hline 2 & $\begin{array}{l}\text { Learning } \\
\text { outcomes }\end{array}$ & $\begin{array}{l}\text { 1. Cognitive } \\
\text { 2. Affective } \\
\text { 3. Psychomotor }\end{array}$ & Questionnaire & Ordinal \\
\hline
\end{tabular}

Data analysis techniques in this study include: data processing includes the editing stage, coding (code generation), and the tabulation stage (code generation). Furthermore, the data in this study will be processed and analyzed using a simple linear regression formula using the SPSS 17.0 program.

\section{RESULTS AND DISCUSSION}

Digital literacy is the ability to use technology and information from digital devices effectively and efficiently in various contexts such as academics, careers, and everyday life (Lotherington \& Jenson, 2011). This opinion seems to simplify the true digital media which consists of various forms of information at once such as sound, writing, and images. Therefore digital literacy should be more than just the ability to use various digital sources effectively (Sonck, Livingstone, Kuiper, \& de Haan, 2011). Digital literacy is also a form of thinking of digital users (Martin, 2005). Currently, the spread of information that occurs in the world is very fast. Sources of information can come from anywhere. Journalists write news and then share them via social media so that the distribution of information moves quickly (Damayanti, 2019)(Wahyuningsih \& Muis, 2020). Not only news written by journalists, news, and information written by ordinary people is often shared via social media such as blogs, Facebook, Twitter, and so on. (Ibda, 2018). The response to the news varies, of course, some support it and vice versa.

So far, literacy is understood as reading and writing activities. Until finally literacy is not only related to reading and writing. But it includes the ability to read, understand, and appreciate various forms of communication critically (Gruszczynska, Merchant, \& Pountney, 2013). In its early development, literacy was defined as the ability to use language and images in rich and varied forms to read, write, listen, speak, see, present, and think critically about ideas. Subsequent developments suggest that literacy is related to social situations and practices. Then, literacy was expanded by the development of information technology and multimedia. After that, literacy is seen as a social construction and is never neutral(Ningsih, 2019). Technological developments in information technology have triggered major changes in digitization technology, namely the condition that all content of print and electronic media can be combined and distributed. Digital literacy is the ability to understand and use information in many formats from various sources 
when it is presented on a computer. Media literacy or digital literacy was developed as a tool to protect people from media exposure so that they can think critically and be able to express themselves and participate in the media(Spera, 2005). Digital literacy includes an understanding of the web and search engines. Digital literacy can also be interpreted as a set of attitudes, understandings, in handling and communicating information and knowledge effectively in various media and formats.

Digital literacy is the ability to relate to hypertextual information in the sense of sequential computer-assisted reading (Boyinbode, Agbonifo, \& Ogundare, 2017). In general, digital literacy is the ability to relate to hypertextual information in the sense of reading non-sequential or nonsequential computer-aided. Media literacy or digital literacy must develop the ability to develop the ability of the audience both intellectually, namely media literacy education in understanding typical media messages(Darmawan, 2019). Develop emotional abilities, feel things conveyed by yourself and others from a message. Developing moral maturity concerning the consequences of morality for everyone (Stone \& Logan, 2018). Media literacy moves to see the bad effects that media messages can have and learn to anticipate them (Awada, 2016). Digital literacy is the knowledge and skills to use digital media, communication tools, or networks to find, evaluate, use, create information, and make use of it in a healthy, wise, intelligent, thorough, precise, and law-abiding manner to foster communication and interaction in daily life(Kurniawati, Maolida, \& Anjaniputra, 2018). Eight essential elements for developing digital literacy, among them are Culture, namely understanding the various contexts of digital users; Cognitive, namely thinking power in assessing content; Constructive, namely the creation of something expert and actual; Communicative, namely understanding the performance of networks and communications in the digital world; Responsible confidence; Creative, doing new things in new ways; Critical in addressing the content; and be socially responsible.

Learning is an effort to teach students to learn (Hamdu \& Agustina, 2011). Learning activities will involve students learning something effectively and efficiently (Bin, Abidin, Esa, Rashid, \& Ahmad, 2010). Learning is the acquisition of a subject or the acquisition of skill through lessons, experience, or teaching (Martínez, Santibanez, \& Mori, 2013). Learning is a combination composed of human, material, facilities, equipment, and procedures that influence the achievement of learning objectives (Andriani \& Rasto, 2019). Learning is a change in behavior that is relatively constant and is the result of repeated practice (Tahar, n.d.). Learning has the meaning that the learning subject must be learned not taught. The learning subject in question is students or also known as learning which is the center of learning activities. Students as learning subjects are required to actively seek, find, analyze, formulate, solve problems, and conclude a problem. Thus increasing learning is the process of changing one's behavior which can be observed and measured in the form of knowledge, attitudes, and skills. This change can be interpreted as a process of improvement that is better than before.

Improvement means processes, actions, ways of improving (efforts, activities, and so on)(Tahar, n.d.). Improvement is a process that is carried out by a person to raise a level of knowledge, skills and so on which is carried out optimally. Learning is a translation of the word "instruction" which means conveying thoughts, thus the meaning of instructional is conveying thoughts or ideas that have been meaningfully processed through learning. Indicators are measures, characteristics, characteristics, manufacturing, or processes that contribute/show the 
achievement of basic competency. Indicators are formulated using measurable operational verbs. Benchmark reference measurements include techniques for determining learning ability to master predetermined material. Benchmark reference measures tell students how far they can reach the specified standard.

As for learning, indicators that can be measured include 3 aspects (Hadi, 2015) namely: a) Cognitive is a domain that includes brain activity. That is, all efforts related to brain activity are included in the cognitive domain. Students are individuals who are actively studying science. In taking the learning process, students are not only passive in receiving knowledge. Students seek information to solve the problems faced and organize this knowledge to gain a new understanding (new insight). An important concept in cognitive is the existence of information processing (Information processing) which consists of knowledge, understanding, application, analysis, synthesis, and affective evaluation. Affective is a domain related to attitudes and values, and a person's attitude can be predicted to change if he already has a high level of cognitive mastery. The characteristics of affective learning will appear in students in a variety of behaviors, such as acceptance, responding, beliefs, organization, and pattern formation. c) Psychomotor is a domain related to skills (skills) or the ability to act after a person has received a certain learning experience. Psychomotor learning outcomes are a continuation of cognitive learning outcomes (understanding something) and affective learning outcomes (the tendency to behave)(Hamdu \& Agustina, 2011). The psychomotor consists of perception, readiness, guided movements, accustomed movements, complex movements, adjustment, and authenticity. learning outcomes are changes in behavior and overall abilities possessed by students after learning, which are in the form of cognitive, affective, and psychomotor abilities caused by experience and not just one aspect of potential. After a learning process ends, students get a learning result.

Learning outcomes have an important role in the learning process (Tahar, n.d.). Learning outcomes are used to determine the extent to which students can understand and understand the material. Learning outcomes become a measurement of the assessment of learning activities or the learning process expressed in symbols, letters, or sentences that tell the results achieved by each child or student in a certain period. Learning outcomes can also be seen through evaluation activities that aim to obtain evidentiary data that will show the level of student ability in achieving learning objectives. Student learning outcomes are influenced by student ability and teaching quality. The quality of teaching in question is the professionalism and expertise possessed by the teacher. This means that the basic abilities of teachers both in the cognitive (intellectual), attitude (affective), and behavioral (psychomotor) fields are very influential in determining student learning outcomes.

Currently, the concept of literacy continues to develop and is divided into several forms of literacy, one of which is digital literacy. digital literacy as an ability to understand and use information from various digital sources. Not only includes reading skills, but it also takes a critical thinking process and evaluates information found through digital media (Uswatun Khasanah \& Herina, 2019). The importance of digital literacy is now also felt by teenagers, especially school students. According to the Education Law no. 2 Th. 1989 refers to several terms pupil, pupil is defined as a person who is in a level of education which in various literature students are also referred to as students. Currently, the learning system is not only limited between teachers and students. With all technological developments, students can now get 
information about anything, including lessons learned from school via the internet. Whether in the form of journals, digital books, or even courses conducted online without the need to meet face to face and are hindered by distance and time. The digital era appears marked by the phenomenon of using the internet by people in everyday life. There are two groups of internet users in today's digital era, namely the younger generation (digital native) and the older generation (digital immigrant)". Talking about digital literacy competencies, it is useful for dealing with information from various digital sources that continue to develop along with the development of information and communication technology as a result of the phenomenon of media convergence. Learning Media (Giovanni \& Komariah, 2020) is the process of combining various mass media and information technology into one technological device which makes it easier for owners to access various information and broadcasts. So convergence is more defined as the integration of the functions of various media into one new, more sophisticated media.

Current and past learning is very different from the existence of technological developments that never stop making innovations. Call it the learning method using laptops and projectors as learning media. Then the learning resources can be obtained from the internet. So many things are obtained from technological developments. The use of digital media among students is only limited as a means of finding sources of information related to learning materials. Furthermore, the use of the internet among students can also communicate with the teacher both personally and through discussion forums. This is done as an effort to deal with the explosion of information available on the internet and to improve student achievement. Learning achievement is the result of learning that is achieved after going through the process of teaching and learning activities. Every learning activity certainly always hopes that it will produce maximum learning. To get good learning achievement is not easy, because student success is influenced by several factors and requires great effort to achieve it. Likewise, the students of UIN Maulana Malik Ibrahim Malang where the authors conducted research. In this technological era, students can use the internet as their learning tool. There have been many achievements by UIN Maulana Malik Ibrahim Malang students such as achievements in the field of graphic design. The demographic situation of a tertiary institution located in the center of Malang makes students exposed to technological developments.

Literacy in the world of education appears officially through government programs. The literacy program in learning has so far only focused on the reading aspect, even though it was not enough in the old literacy because it required the ability to write and read. To develop Higher Education as a learning organization, the Ministry of Education and Culture develops the School Literacy Movement (GLS). GLS is a comprehensive effort that involves all campus residents (lecturers, students, parents/guardians of students) and the community, as part of the education ecosystem. GLS strengthens the growth of character as stated in the Regulation of the Minister of Education and Culture Number 23 of 2015. One of the activities in the movement is in the form of reading 15 minutes of non-learning books before learning time begins. In practice, GLS only refers to old literacy skills. To answer the era of society 5.0, literacy competence must be strengthened. With a simple approach, the learning outcomes are relevant to the new literacy spirit. At the end of January 2020 yesterday, issued a new literacy idea. This discourse is related to Indonesia's readiness to face a society 5.0 era. 
Facing the era of society 5.0 requires "new literacy" in addition to old literacy. There needs to be a new reorientation in the implementation of education, both in primary, secondary, and tertiary education. The goal is that the world of education still has relevance in the era of society 5.0. In the learning process, teachers and lecturers need to integrate the learning outcomes of the three fields in an integrated manner, namely the achievements of the old literacy, new literacy, and scientific literacy. In practice, this strengthening can be done with several approaches. First, to understand data literacy, children in learning must be taught to understand data, be it qualitative, quantitative, or the information that is consumed. Second, technological literacy is translated into the ability of Indonesian human/human resources to make various breakthroughs in innovation, increase the ability to use internet information optimally, expand access, and increase cybersecurity protection. The literacy tradition must be strengthened by the application of the pillars of literacy, namely "read, write, archive". What is read must be written, what is written must be read. It can be in the form of books, journals, proceedings, papers, scientific papers, articles, and others. 32 In learning at school there must be a "literacy teacher" who can teach children to achieve high literacy. In the practice of literacy learning, the formula for the literacy understanding stage is divided into three stages, namely proliferation, literacy, and postliteracy.

This research was conducted by the authors at the Social Studies Education Department, Tarbiyah and Teacher Training Faculty, in the Subject of Development of Learning Resources and Media UIN Maulana Malik Ibrahim Malang. Is one of the universities that has implemented digital literacy in the teaching and learning process, this application was carried out by several lecturers. UIN Maulana Malik Ibrahim Malang has a goal of fulfilling quality, efficient, relevant, and highly competitive education. Therefore, in the process of improving learning, it is carried out by implementing digital literacy. The respondents in this study were 77 students who were taken through a purposive sampling technique, namely the sampling technique based on certain considerations. Based on the results of the research that the author has done, that the application of digital literacy has a strong effect on improving student learning in the Social Studies Education Department, Tarbiyah, and Teacher Training Faculty, UIN Maulana Malik Ibrahim Malang. Based on the research results, it was obtained $\mathrm{R}$ of 0.667 , which indicates that the relationship between the application of digital literacy (variable $\mathrm{X}$ ) and learning outcomes (Variable Y) is strong. The results of the F test prove that F 68,688> F 4.39, then the alternative hypothesis $(\mathrm{H})$ is accepted and the null hypothesis $(\mathrm{H})$ is rejected. Thus, it can be stated that the application of digital literacy influences on improving learning outcomes. While the results of the coefficient of determination obtained a value of 0.458 , indicating that the independent variable affects the dependent variable by $45 \%$. Meanwhile, $55 \%$ is influenced by other factors that were not examined in this study. 


\section{CONCLUSION}

Digital literacy is the ability to understand and use information in various forms from a very wide variety of sources accessed via computer devices. Learning Outcomes are learning achievements which are the results of learning activities, namely the extent to which students master the subject matter being taught, which is followed by the emergence of a feeling of satisfaction that he has done something well. The application of digital literacy affects the improvement of student learning outcomes of the Social Science Education Department, Tarbiyah and Teacher Training Faculty, in the Subject of Development of Learning Resources and Media UIN Maulana Malik Ibrahim Malang. This is evident from the simple linear regression analysis by obtaining a correlation coefficient value of 0.667 , which means that there is a strong influence of the effect of digital literacy on improving the learning outcomes of students of the Social Studies Education Department, Faculty of Tarbiyah, and Teacher Training, in the Resource Development Course and Learning Media of UIN Maulana. Malik Ibrahim Malang.

\section{REFERENCES}

Andriani, R., \& Rasto, R. (2019). Motivasi belajar sebagai determinan hasil belajar siswa. Jurnal Pendidikan Manajemen Perkantoran, 4(1), 80. https://doi.org/10.17509/jpm.v4i1.14958

Asari, A., Kurniawan, T., Ansor, S., Bagus, A., \& Rahma, N. (2019). Kompetensi Literasi Digital Bagi Guru Dan Pelajar Di. BIBLIOTIKA: Jurnal Kajian Perpustakaan Dan Informasi, 3, 98-104. Assidik, G. K. (2018). Pemanfaatan Media Sosial Sebagai Alternatif Media Pembelajaran Berbasis Literasi Digital yang Interaktif dan Kekinian. Seminar Nasional SAGA Universitas Ahmad Dablan, 242-246. Retrieved from http://seminar.uad.ac.id/index.php/saga/article/viewFile/124/370

Awada, G. (2016). Effect of whatsapp on critique writing proficiency and perceptions toward learning. Cogent Education, 3(1), 1-25. https://doi.org/10.1080/2331186X.2016.1264173

Bin, R., Abidin, Z., Esa, A. B., Rashid, M., \& Ahmad, B. W. (2010). PENDIDIKAN SEPANJANG HAYAT: SEKOLAH PENERAJU UTAMA MENJANA GENERASI TERBILANG. Seminar Kebangsaan Pengurusan Pendidikan PKPGB 2009, 7 Mei 2009, UTHM PENDIDIKAN, 8(5), 10.

Boyinbode, O. K., Agbonifo, O. C., \& Ogundare, A. (2017). Supporting Mobile Learning with WhatsApp based on Media Richness. Circulation in Computer Science, 2(3), 37-46. https://doi.org/10.22632/ccs-2017-251-89

Damayanti, I. (2019). Optimalisasi Literasi Digital Dalam Pembelajaran Bahasa Indonesia Sebagai. 3, 1004-1009.

Darmawan, D. (2019). 済無No Title No Title. Journal of Chemical Information and Modeling, 53(9), 1689-1699. https://doi.org/10.1017/CBO9781107415324.004

Fajeriah, S., Tadulako, U., \& Indonesia, P. (2021). THE EFFECT OF OFFLINE LEARNING MODEL ASSISTED IN PRACTICUM DISCOVERY LEARNING ON LEARNING. 4(3), 663-671.

Fransori, A., Sulistijani, E., \& Youlinda Parwis, F. (2019). Penyuluhan Pola Asuh Orang Tua Terhadap Anak Dalam Penguatan Pendidikan Karakter Anak Dan Literasi Digital Pada Ibu- 
Ibu Majelis Taklim Al-Hidayah Depok. Jurnal Pengabdian Masyarakat (JPM-IKP), 2(01). https://doi.org/10.31326/jmp-ikp.v2i01.259

Giovanni, F., \& Komariah, N. (2020). Hubungan Antara Literasi Digital Dengan Prestasi Belajar Siswa Sma Negeri 6 Kota Bogor. LIBRARIA: Jurnal Perpustakaan, 7(1), 147. https://doi.org/10.21043/libraria.v7i1.5827

Gruszczynska, A., Merchant, G., \& Pountney, R. (2013). "Digital futures in teacher education": Exploring open approaches towards digital literacy. Electronic Journal of E-Learning, 11(3), 193-206.

Hadi, B. (2015). Pengembangan ICT dalam Pembelajaran Pengembangan ICT dalam Pembelajaran. Pengembangan ICT Dalam Pembelajaran, (November), 36-44.

Hamdu, G., \& Agustina, L. (2011). PENGARUH MOTIVASI BELAJAR SISWA TERHADAP PESTASI BELAJAR IPA DI SEKOLAH DASAR (Studi Kasus terhadap Siswa Kelas IV SDN Tarumanagara Kecamatan Tawang Kota Tasikmalaya). Jurnal Penelitian Pendidikan, 12(1), 81-86.

Ibda, H. (2018). Penguatan Literasi Baru pada Guru Madrasah Ibtidaiyah dalam Menjawab Tantangan Era Revolusi Industri 4.0. Journal of Research and Thought of Islamic Education, 1(1), $1-21$.

Khokhar, A. S. (2016). Digital Literacy. International Journal of Digital Literacy and Digital Competence, 7(3), 1-12. https://doi.org/10.4018/ijdldc.2016070101

Kurniawati, N., Maolida, E. H., \& Anjaniputra, A. G. (2018). The praxis of digital literacy in the EFL classroom: Digital-immigrant vs digital-native teacher. Indonesian Journal of Applied Linguistics, 8(1), 28-37. https://doi.org/10.17509/ijal.v8i1.11459

Lotherington, H., \& Jenson, J. (2011). Teaching multimodal and digital literacy in L2 settings: New literacies, new basics, new pedagogies. Annual Review of Applied Linguistics, 31, 226-246. https://doi.org/10.1017/S0267190511000110

Martin, A. (2005). DigEuLit - a European Framework for Digital Literacy: a Progress Report. Journal of ELiteracy, 2, 130-136.

Martínez, J. F., Santibanez, L., \& Mori, E. E. S. (2013). Educational opportunity and immigration in méxico: Exploring the individual and systemic relationships. Teachers College Record, 115(10), 11-21.

Ningsih, T. (2019). Peran Pendidikan Islam Dalam Membentuk Karakter Siswa Di Era Revolusi Industri 4. 0. 220-231.

Pratiwi, N., \& Pritanova, N. (2017). Pengaruh Literasi Digital Terhadap Psikologis Anak Dan Remaja. Semantik, 6(1), 11. https://doi.org/10.22460/semantik.v6i1p11.250

Sonck, N., Livingstone, S., Kuiper, E., \& de Haan, J. (2011). Digital Literacy and Safety Skills. Educational Research, 1-4.

Spera, C. (2005). A review of the relationship among parenting practices, parenting styles, and adolescent school achievement. Educational Psychology Review, 17(2), 125-146. https://doi.org/10.1007/s10648-005-3950-1

Stone, S., \& Logan, A. (2018). Exploring Students' Use of the Social Networking Site WhatsApp to foster connectedness in the online learning experience. Irish Journal of Technology Enhanced Learning, 3(1), 42-55. https://doi.org/10.22554/ijtel.v3i1.28

Sugiyono. (2012). Metode Penelitian Kuantitatif, Kualitatif dan R \& D.Bandung:Alfabeta. Metode Penelitian Kuantitatif, Kualitatif Dan $\mathrm{R}$ \& D.Bandung:Alfabeta. https://doi.org/10.1017/CBO9781107415324.004 
Suliyanto. (2018). Pelatihan Metode Pelatihan Kuantitatif. Journal of Chemical Information and Modeling, 5(2), 223-232. https://doi.org/10.1017/CBO9781107415324.004

Tahar, I. (n.d.). Hubungan Kemandirian Belajar Dan Hasil Belajar Pada Pendidikan Jarak Jauh.

Tinggi, K. P. (2019). Panduan Penyusunan Kurikulum. Belmawa, Kemristekdikti.

Uswatun Khasanah, \& Herina. (2019). Membangun Karakter Siswa Melalui Literasi Digital Dalam Menghadapi Pendidikan Abad 21 (Revolusi Industri 4.0). Prosiding Seminar Nasional Pendidikan Program Pascasarjana Universitas Pgri Palembang, 21, 999-1015.

Utami, R. (2019). "Innovation in Islamic Education: Challenges and Readiness in Society 5.0" INTEGRASI KURIKULUM DI INDONESIA DALAM MENGHADAPI ERA SOCIETY 5.0 Rizka Utami. 4th International Conference on Education, 213-218.

Wahyuningsih, D., \& Muis, A. R. (2020). Male Students' Reading Comprehension Difficulties. AL-ISHLAH: Jurnal Pendidikan, 360-371. https://doi.org/10.35445/alishlah.v12i2.265 